\title{
THE FEATURES OF ENTREPRENEURIAL INTERACTIONS IN THE AGRICULTURAL SECTOR IN TERMS OF INSTITUTIONAL TRANSFORMATIONS
}

\author{
Maksym Odnorog ${ }^{1}$, Nataliia Kraus², Kateryna Kraus ${ }^{3}$
}

\begin{abstract}
Entrepreneurship is one of the pillars of the economy of the country and covers all sectors irrespective of ownership forms. Currently, this activity is increasingly spreading in rural areas. Our research results on transformation in the agricultural sector of the economy show that it is due to the development of entrepreneurship and strengthening entrepreneurial orientation and improvement of business environment economic entities in rural areas they were able to quickly and efficiently adapt to market conditions and to enter the foreign market, therefore, the purpose of the paper is to define the basic principles and the principles of entrepreneurial activity, its specifics and trends in agriculture and rural areas, to show the beginning and the development of collective and individual entrepreneurship. Methodology. The theoretical and methodological basis of the research is the dialectical method of cognition and systematic approach, through which theoretical and methodological foundations of the development of business interactions in the agricultural sector in terms of institutional transformations. The results showed that in the article, the methodical design determining the nature and characteristics of agricultural business organically integrated the concept of institutional knowledge of the economic order, which allows us to identify the evolutionary concept of the formation of enterprises; the structure of the institutional system of entrepreneurship in the context of the evolution of this concept. Practical implications. The studied institutions create incentives for the development of science and education, encourage the mobility of production factors, and facilitate the transfer of scientific and technical information and the introduction of new technologies, promoting entrepreneurship and innovation. Conversely, inefficient institutions reduce the potential level of well-being, reduce reliability assurance of property rights, and enforce contracts. Value/originality. Given systematic and analytical characteristics of the effects, significance, dynamics of development of agrarian entrepreneurship in the context of institutional transformation, show the paradox, the stability of the institutional environment will not soon be reached, therefore, the dilemma of institutions remains unresolved. In general, the institutional transformation has ensured the formation of a mixed economy, the real pluralism of forms of ownership and agricultural management even if they are not yet fully institutionalized in the market. Transformations in the business environment we call the transformation of institutional conditions for the development of economic formations. Institute of entrepreneurship for the imperfections of the rules and conditions of economic interactions has not yet become mutually beneficial by the Institute for functional participants. Analysis of the development of agrarian enterprises in the conditions of institutional transformations proves the inconsistency of the institutional framework of entrepreneurial activity, which leads to a decrease in the number of enterprises - economic entities, non-transparent activities of business entities, the removal of landlords from participation in the activities of enterprises.
\end{abstract}

Key words: agricultural entrepreneurship, institutions, legal forms of enterprise, market relations, transformation processes in agrarian economy.

JEL Classification: Q10, Q11, Q12, Q13, Q14, M13, L14, N50, F33, G20

\footnotetext{
Corresponding author:

${ }^{1}$ State Educational-Scientific Institution "Academy of Financial Management”, Ukraine.

ORCID: https://orcid.org/0000-0002-6650-6181

E-mail: odnorog btnau@ukr.net

${ }^{2}$ Borys Grinchenko Kyiv University, Ukraine.

ORCID: https://orcid.org/0000-0001-8610-3980

E-mail: k2205n@ukr.net

${ }^{3}$ Borys Grinchenko Kyiv University, Ukraine.

ORCID: https://orcid.org/0000-0003-4910-8330

E-mail: k23k@ukr.net
} 


\section{Introduction}

In conditions of market transformation of the economy of Ukraine, entrepreneurship development should become one of the most important factors of socio-economic growth, the real engine of the economy. Active development of entrepreneurship helps to attract to entrepreneurial activities a larger number of capable, outgoing people, provides for the best use of all material and social resources, intensive development of the national economy, increasing national wealth and well-being of the nation. Entrepreneurship is both cause and consequence of the formation of a market economic system in Ukraine. It is the driving force of economic activity of all subjects of market relations. Entrepreneurship as a socio-economic phenomenon is always the centre of attention of theorists and practitioners. Thanks to entrepreneurship in most countries, it creates new jobs and innovates, develops new markets and businesses, increases tax revenues and incomes of the population. It is the basis of development of individual sectors of the economy and the state as a whole.

Entrepreneurship is one of the pillars of the economy of the country and covers all sectors irrespective of ownership forms. Currently, this activity is increasingly spreading in rural areas. Our research results on transformation in the agricultural sector of the economy show that it is due to the development of entrepreneurship and strengthening entrepreneurial orientation and improvement of business environment economic entities in rural areas that they were able to quickly and efficiently adapt to market conditions and to enter the foreign market.

However, according to our estimates, theoretical developments and practical experience are insufficient to agricultural business structures; it was competitive in the conditions of European integration processes and in the global economy. Separately in a given system of socio-economic relations is the agricultural enterprise, which is the functional priority of the promising development not only of the eponymous industry and the economy as a whole. We consider scientifically and practically motivated research on the development of agricultural entrepreneurship under conditions of institutional transformations that, in particular, was the "saving grace" for the domestic economy, despite the regularity of crises.

\section{Analysis of recent researches and publications}

The analysis of literary sources on the issues raised carried out to build our own vision of the theory of the problem showed that the fundamental principles and methodology of entrepreneurship are most fundamentally implemented (Schumpeter, 2011).

Using the author's own vision of the foundations for the development of agricultural entrepreneurship, there is an appeal to the doctrine J. Schumpeter, which is characterized by its consistency and depth of judgment than celebrate his successors and domestic contemporaries. In the development of such an ideological background to the analysis, the researchers note that the doctrine of J. Schumpeter is a classic, fundamental work, in which the universally accepted measurement defining scientifically designed innovative implication of the development of economic relations, which in his incarnation building a system of value creation. However, the prospect of the development of modern social formations depends on the dynamics of the effects of the entrepreneurial process. You can disagree with the conclusion of Ju. Bazhal in the European Union, presented in the preface to the Ukrainian translation of the classic work of Joseph Schumpeter "The Theory of Economic Development: An Inquiry into Profits, Capital, Credit, Interest and the Business Cycle" (Schumpeter, 2011) that "two taken in the twenty-first century ten-year development strategies - the Lisbon (2000-2010) and the current Europe 2020 (2011-2020) to actually implement it conceptual paradigm, where the central driving factor of economic growth is the generation of new knowledge for innovative development" (Schumpeter, 2011). The objectivity of judgments of such a plan is confirmed by the practice because purchased welfare effects of modern Europe - a real example of the effectiveness of the principles of the embodiment of the concept of economic relations by ensuring consistent institutionalization.

Further researchers largely follow the ideas of entrepreneurship regardless of the industry sector and its institutionalization as an activity aimed at receiving profit at the expense of universal innovation is an absolute attribute of the fundamental studies on entrepreneurship.

Among the scientific moderators of problems of entrepreneurship, including agricultural, in the context of institutional transformations, the methodology of institutional discourse should be highlighted of such researchers as: (Bergman, 1969), (Varnalij, 2006), (Balakirjeva, 2015), (Nour, 2015), (Grebenjuk, 2014), (Gubeni, 2012), (Kredisov, 2003), (Lupenko, 2012, 2016), (Sabluk, 1997), (Andrijchuk, 2013), (MeselVeseljak, 2010), (Pashaver, 2013), (Mazur, 2012), (Zbarskyj, 2015), (Jerohin, 2002), (Lopatynskyj, 2006), (Prutska, 2003), (Commons, 1931), (Khandker, 2016), (Koolwal, 2016), (Campbell, 2004), (Freeman, 1987), and others. Issues of institutional development of the agrarian sector also disclosed in the publications of the authors (Lupenko, 2016), (Malik, 2011, 2013), (Shpykulijak, 2009, 2016), however, we consider it necessary to strengthen the scientific construct of the disclosure of the institutional paradigm of the development of agrarian entrepreneurship in the dynamics of its formation and the formation efficiency. 
The goal of the article is to define the basic principles and the principles of entrepreneurial activity, its specifics and trends in agriculture and rural areas, to show the beginning and the development of collective and individual entrepreneurship.

The theoretical and methodological basis of the research is the dialectical method of cognition and systematic approach, through which there are theoretical and methodological foundations of the development of business interactions in the agricultural sector in terms of institutional transformations.

\section{The structure of the institutional system of entrepreneurship}

The theory of entrepreneurship is considered to be well-established scientific doctrine about the nature and principles of economic development, innovation-based growth. In the most conceptually well-established, recognized scientific and practical context, there is the concept of entrepreneurship as the Institute for market interactions that are associated with risk, competition for limited resources, but are directed to making a profit.

The methodology of Schumpeter's scientific and practical understanding of entrepreneurship is currently the basis for the formation and conduct of economic policy in almost all developed countries. According to Schumpeter, an entrepreneur can be considered one who creates an enterprise and opens the business; introduces new methods of production; discovers and develops new markets; develops new sources of raw materials; reorganizes industry, and creates new enterprises. As to the entrepreneur, Schumpeter differs from "just host" behaviour and motives of economic activity and outlook. He carries on a constant search for new, improved products quality, has enough will and capacity to overcome the resistance of the competitors, affects the other, the results of their success, and effort and energy (Schumpeter, 2011). A business function is identified with the function of economic leadership and innovation, and innovation is considered the basis of entrepreneurship. Having formed the concept of entrepreneurship, he stressed the need for novelty the entrepreneur remains the same as long as carries out "new combinations". This opinion on entrepreneurship was also presented by F. von Hayek. However, the main in business he saw personal freedom that allows a person to productively use their abilities and knowledge and information and economic potential.

Entrepreneurship as a phenomenon, an economic activity, and an object of scientific knowledge is characterized by the complexity of the practical expression of the functions and definitions of substantive characteristics. It is, therefore, acceptable to refer to the structure of the scientific discourse on entrepreneurship in addition to the purely economic, as we believe, interdisciplinary synthesis. Given the assertion presented in the formation of scientific discourse as the moderation of an affirmative conclusion, the enterprise pursues not only economic but also social, philosophical, anthropological, and, of course, institutional nature. In other words, entrepreneurship as a phenomenon, process, and institution becomes the practice of being through the economy and society.

Economy because of the specific and the agricultural sector even more so, imitate the system of institutional transformations, because they are in constant evolution. Quite appropriate for the perception in the scientific community has concluded A. Mazur that "...the fundamental contradiction of modernity lies in the institutional nature of socio-economic transformation, namely between a state-initiated market transformation that uses incompatible with the logic of the transformation of regulatory methods" (Mazur, 2012). Marked the context of the evaluation of the design of domestic institutional transformation, it is characteristic in particular for the agricultural sector regarding the formation of the Institute of entrepreneurship.

Support of entrepreneurial activities and stimulation of innovative development are based on creating the appropriate institutional conditions for market, legislative and organizational support, the relationship between the state and business structures and other social institutions.

Under the economic category "Institute" we will understand the situation in the course of evolution rules, regulations and restrictions of the interaction of individuals. Institutions interact to form integrative integrity, which is experiencing transformational change.

In practice, economic actors are operating in different subsystems, where there are problems associated with the need to constantly take into account the standards of conduct and restrictions. It is proposed to allocate in the institutional system the following components (Figure 1).

The recognition of entrepreneurship as an activity aimed at receiving profit-related risk is a rational approach. Last offer as the quintessence of the scientific thoughts of $\mathrm{M}$. Weber on rational evidence which invests in its definition the content of the conclusion that: "there is rational evidence, especially when the structure of the implied meaning of the action entirely understood intellectually" (Weber, 2016).

To refer to the business process, the term "entrepreneurship" (entreprende - FR.) is introduced by Richard Cantillon at the end of the XVII century. By the definition, entrepreneurship is an activity related to risk in the organization of a particular enterprise, production, business.

In economic literature, one can find many definitions of entrepreneurship, but they are controversial (Gubeni, 2012). This can be explained by the complexity of this concept. Some missed the risk, others regularity, relation to state registration, social results. 


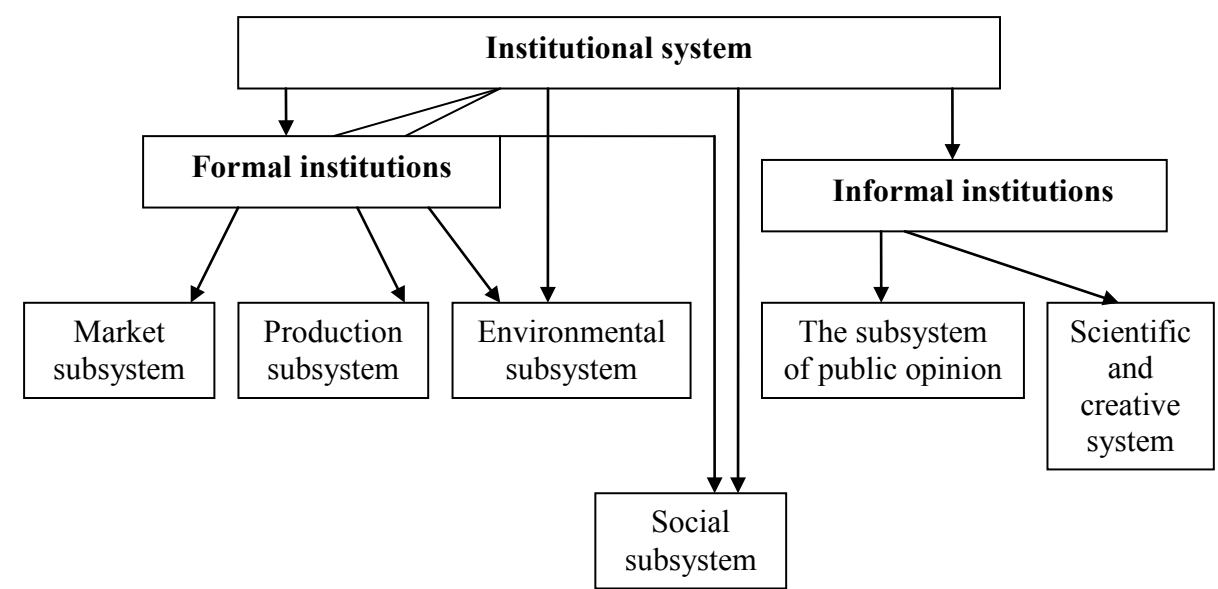

Figure 1. Structure of the institutional system of entrepreneurship

Source: developed by the author

Such activities are quite often denoted by the terms "business" and "entrepreneurship". In our opinion, they are synonymous, although there are definitions which interpret "business" as a broader concept, which includes employment.

In our particular case, nature and functional characteristics of entrepreneurship are "intellectually understandable". Therefore, we believe the correct and reasonable is the universal definition of entrepreneurship as independence, initiative, at your own risk activity aimed at profit. The issue of entrepreneurship is multidimensional; it is treated in the economic, political, and sociological terms.

In particular, the sociological interpretation of entrepreneurship in the construction of a common discourse about this phenomenon is based on the fact that the implementation of this activity is related to the motivation of the individual, in which its efficiency is of economic interest. General sociology on the essence of entrepreneurship is extremely difficult because the entrepreneur can become not every individual, but only the one that has the relevant skills. In the sociological dimension, entrepreneurship is examined in the context of the statements of M. Weber as a "rationally oriented target actions" (Weber, 2016), that is, acts of the entrepreneur by the nature of socialization is rational.

The economic context of the definition of entrepreneurship, acquired by science, and J. Schumpeter represented as due to a combination of organizational resources in the implementation of the act of production on the principles of innovation (Schumpeter, 2011). While such a combination is believed an instrumental system of creation of wealth to meet public needs, which operates under certain institutional conditions.

Scientific inquiry and the ideology of research priorities, theory and methodology of entrepreneurship are evidence of the breadth of the subject of discourse. Now the science of entrepreneurship is extremely versatile in structuring its specific characteristics. Under the characteristic of entrepreneurship, one understands the effect of its influence on the socio-economic process for the supply of goods to the market. This, in particular: social entrepreneurship (produces social benefits); economic (economic benefits); institutional (institutional benefits). The deepening of the theory of entrepreneurship does not mean a departure from the fundamental theoretical postulates laid down by Schumpeter (Schumpeter, 2011), it is a consequence of institutional transformations that occur in a dynamic economic life. In fact, as pointed out by Schumpeter, entrepreneurship itself acts as a designer, universal, constant transformation, modernization, through the unconditional desire of earning more profit. In our opinion, it can be argued that entrepreneurship is the "centre of gravity" of a society, institute, and which to this day revealed all existing milestones of scientific progress.

The entrepreneurial model of economic relations in a theoretical sense - imitations of scientific results showing its universal relevance. Therefore, we believe a constructive attitude that the methodology of knowing the positioning of this social phenomenon has significantly expanded the scope of discussion, has entered the era of universal interdisciplinarity. In practical terms, it is confirmed, because in the developed market economies, all activities on the creation and consumption of wealth inherit the principles of entrepreneurship. Entrepreneurship more and more acts in the direction of institutions in the information field of the economy, acquiring not only a purely industrial nature.

The study of problems of entrepreneurship incorporates the ideas of institutionalism, which treat entrepreneurship as an institution - an institutionalized system of rules. This is seen as its (business) interdisciplinarity, signs of a shift in the methodology of the transformation of the environment of socioeconomic interactions of individuals. Overall, 
entrepreneurship as an institution is a tool, which forms the basis for the realization of interests of market agents.

Taking into account the domestic realities of evaluation of entrepreneurship, we note that its agrarian aspect for Ukraine defines in a broad format the practice of nursing, but is in a long period of institutional transformation, still in progress. The specificity of institutionalization in an agricultural enterprise like any other institution is a way of applying resources subject to competitive market but dependent on nature that we pay attention.

The business entities in the market act as entrepreneurial structure, due to the law of competition, interact in the conditions defined by the state, the market, and relevant institutions-conductors in institutional order. We believe that the institutional order is an ordered and formal (or) informal rules, system rules of behaviour of market agents, within the limits and under the action of which they are forced to grow, reaching a certain goal. That institutional order, a variation of which for the agricultural enterprise is a business, builds a system of constraints, incentives, and balances to ensure appropriate business transactions, doing that, the entrepreneur inherits the classic situation ... "is valid in terms of risk, directing their efforts on an effective combination of resources and capital for profit".

A domestic agricultural enterprise is characterized by frequent institutional traps caused by defects in institutionalization. In practice, the entrepreneur imitates the current institutional (and economic) order or tries to work around it by breaking the rules. This is the paradox of risk because of certain situations that can line up with the actions of the entrepreneur, or be embedded in the existing institutional order, the institutional entrepreneur falls into a trap, which deteriorates the level of institutional security. The dilemma of institutional trap for the entrepreneur - the objective inability to solve any situation of a legitimate, competitive way for profit, so there is a choice to break the rules, right or not to break and "play". Usually, the entrepreneur motivates his actions, the solution to this kind of situation and that is the nature of entrepreneurship.

For agricultural entrepreneurship, which long time is conducted in the conditions of incomplete reformation of the market structure of managing in Ukraine and, consequently, institutional transformations, this aspect of the detection of the deterioration of the institutional security is the evidence admissible in the framework of our research. Considering the issue of institutional security for the development of agricultural entrepreneurship is important given the long institutional transformation of the way of business, which is still ongoing.

\section{Institutional business security}

In society, the economy, the market, the institutional system as a whole determine the different types of security that are "focused" on specific signs of their manifestations (economy, energy, policy, and political security). Everything seems simple and clear but the institutional security is a specific construct of status positions of economic agents in relation to the "quality" institutions and the "quality" of institutions in relation to economic agents (Schumpeter, 2011).

The concept of "institutional security" also belongs to the discourse about the nature of agro-entrepreneurship. Institutional security is the fact counter to institutional trap, which arises in the exchange process, forming the level of transaction costs, the market ability to be effective in relation to the economic agents, the motivation of their activities in a market system of coordinates. Institutional security is the result of a certain level of institutional mobility of participants of market exchange, so the measurement of effects, e.g. competition, it represents the relevance of institutional norms and their functional efficiency. Institutional safety must be considered a manifestation of efficiency, especially market institutions, i.e. institutional effectiveness, and also an expression of institutional protection from the abusive behaviour of actors in the system of relations between agents. This is also the level opportunities available at security from the competitive behaviour of the stakeholders in terms of institutional verification of their place and role in positions that do not harm their partners (Schumpeter, 2011). Variations in the levels of institutional security (Table 1) built-in system of influence of institutions in the environment of institutionalization (mainstreaming) of norms, traditions, laws, which means primarily the form of changing the status of an object, and hence business activities.

Table 1

Variations of the levels of institutional security of entrepreneurial activity in the conditions of operation of the market mechanism

\begin{tabular}{|c|c|c|}
\hline Level & Moderator & Fund institutional security \\
\hline First & Employee & The welfare of the individual \\
\hline Second & The company & Business competitiveness \\
\hline Third & State (economy, national market) & The creation and redistribution of the social product \\
\hline Fourth & The global economy and the market & $\begin{array}{c}\text { Global competitiveness and the institutional adaptability } \\
\text { of the economy }\end{array}$ \\
\hline
\end{tabular}

Source: developed by the author 
In terms of expressions of institutional security, we should not forget about the consequences of modification of institutions in the case of reorientation, and transformational change, restructuring the model of economic order, for example, the transition from a command-administrative to a market-competitive economy.

Here also are aspects of institutional security, caused by the transplantation of institutions, as well as creating new ones, which can cause the rejection of economic agents. Based on the foregoing, under institutional safety one can understand the relevance of institutional norms and their functional effectiveness in relation to economic agents in the process of diffusion (diffusion of institutional norms).

In a given context, judgments and methodological generalizations in the area of the selected field of institutional discourse, we note that transplanted borrowed the institutions, institutions can create both institutional security and the dangers of institutional entrepreneurship; emphasize this and draw attention. Sometimes specific institutions are not perceived to be available in society, the economy, the institutional system due to the peculiarities of the socio-economic model of relationships, institutional traditions. For example, the expression "reforms don't go" is a codification of institutional effects, public choice, shaped by the interaction and the main contradictions between "new" and "old" institutions. For this reason, our national economic existence inherits a lot of examples, that is, there are situations when new institutions are not perceived, acquire the status of an outcast, and that is a fact of institutional risk, which adversely affects the effects of the economic process, the level of welfare. In particular, the institution of private property, despite the long period of reformation processes for the approval of the market until it was seamlessly integrated into the economic system in a competitive and mutually beneficial to all participants in market exchange. A vivid example - the agricultural sector agricultural entrepreneurship, the right to private land ownership - institutional implementation is piecemeal, because implemented in economic practice only in the context of the tenancy and Institute the sale is not valid, therefore, to a certain extent, institutional risk, which practically manifests the imperfection of the system of redistribution of value, not motivation owners, limiting the rights of their activity in the implementation of long-term investments. In general, agrarian entrepreneurship in modern Ukraine still imitates the effect of the instability of the institutional environment of management.

Formation of the theoretical foundations of entrepreneurship development requires the definition of our relationship, in the methodological basis of which lies the direction of scientific cognition of objects and phenomena, based on evolutionary methodologies.
A substantial body of research objects of this school is such basic categories as an institution and the institution, interpretation of nature - the importance of which constructs the ideological basis, targets for learning. The contours of institutionalism are extremely versatile, so we recognize the complexity of the problem, but still try to crystallize the priorities of research practices, drawing on established subject and method of institutional economics. The emphasis on "efficiency" is made on the basis that the activities of entrepreneurs are purely economic one for object entities, an interpretation of the effects. This is especially a specific direction of scientific knowledge, which interpreter path the causes of certain results of the development of social-economic processes as consequences of the rules of the game-institutions, as well as their consolidation in the form of complex economic systems - organizations, institutions, codes of economic behaviour.

Proof of this is the economic reality, because the market, state, and society live by certain rules, which anyway adhere to the running behaviour of economic agents, particularly entrepreneurs, which ultimately creates the effect of regulations. Besides, economics is a social science, which in initiated of philosophy - the original methodology and institutionalism. In our belief, the unidentified faces of institutionalism in relation to the economic processes associated with the actions of the market entities and the state are very vague and it gives the opportunity to know it in the progressive acquisition of new knowledge, including about the economy. Still real economic institutions produce diverse effects, including regulatory issues, the results of which determine certain well-being and satisfaction of the needs of society. The quality of institutions and hence their functional efficiency determine the level of welfare of the population - on this point of reality, including in the global context of competitiveness, which is also projected on the foundations of the institutional transformation of the agrarian entrepreneurship.

Entrepreneurship is positioned in the institutional environment as a specific, specialized functional entity, which is subject to regulatorymechanisms-competition, pricing, infrastructure, cooperation, clustering, state management. The task of each of them is normalized by the institutions recognized by the state, society, market and they are implemented through institutions - public, market, and established state regulations. In relation to the enterprise of the clause under consideration, depending on their regulatory impact - it can be direct and indirect state regulation, self-regulation through the market, on-farm management.

Of course, following a market approach in the scientific and methodological positioning of the institutionalization of entrepreneurship, one of the most important, most influential in this particular case, we consider mechanisms of competition. Competition is an institutional mechanism - the ideology of market 
interactions that regulate "life" of the entrepreneur in the constant struggle for resources and markets for goods, i.e. the consumer. Besides, the market mechanism is designed a certain framework of institutionalizing entrepreneurship, and consequently, the level of transaction costs and efficiency.

The mechanism of competition, thanks to the works of T. Hobbes, B. Mandeville, I. Newton, C. Darwin, $\mathrm{H}$. Spencer, is perceived as the institutional framework, the basic reference point in the development, provision, and implementation of business initiatives, which in the modern sense and the institutional anchoring are the basis of public prosperity. The competition mechanism in the classical sense sets certain limits for economic agents, and hence entrepreneurs. Institutions, i.e. rules of the competition, who designs an eponymous mechanism, inherited the ideology of the market as the medium of interaction of economic agents (entrepreneurs), each of which seeks to obtain the resources as cheaply as possible, quality workforce and employing them to produce the product and to realize it in the markets at a price level, which will allow obtaining higher under certain conditions being equal income. The competition mechanism is a complex set of multidimensional factors influence on the entrepreneurial process, under the action of which is formed a new quality of the social product.

\section{Institutional transformation of the agrarian sector of the economy of Ukraine}

Institutional transformation of the agrarian sector of Ukraine's economy still led to distinctive national traditions of the market model of agriculture, no matter what level of perfection it acquired, respectively - this applies to the agricultural enterprise. We agree with the conclusion of academician of NAAS Y. Lupenko that "at present, the development of agriculture occurs on the model prevailing in the transition period, under the influence of the reform. This model... is now a multi-element, diverse, and includes at least four economic structures (Table 2): private farms (farmers, private enterprises), corporate (agricultural companies, cooperatives), public (the public) and family (households)" (Malik, 2011).

For now, more family farms form the company, which is legally standardized recently and is intermediate between the farmers and the households, it can still be called transitive, or hybrid (ed.) - essentially different types, forms farmers believe the paradox of the national institutional transformations in the development of the agrarian entrepreneurship.

However, from a functional point of view, regarding the development of the agrarian entrepreneurship "... industries are undergoing structural changes associated with the expansion of the activities of big business, increasing the production of export products and products that are in high demand" (Malik, 2011). The industry is progressing, despite the fact that the effects, costs, and the level of satisfaction of needs of a society are focused on resource model of innovating type - the so-called "survival mode".

Pronounced believe in the existence of pluralism of organizational forms of agricultural entities, which gives grounds to speak about the differentiation of their competitiveness, which is indicative of the fact of evaluating the development of agricultural enterprises.

When talking about the development of agricultural entrepreneurship under conditions of institutional transformation and focus on analytics, the efficiency of development of business entities of agrarian profile in Ukraine's economy is represented in Table 3.

The subjects of entrepreneurial activities depending on the specific objectives of the study are divided into industrial, commercial, and financial. According to the scope of activities, enterprises are divided into small, medium, and large.

Operating experience says that equal volumes of activity of business structures complement each other and find their market niches. Major business organizations have their advantages in the market due to the scale of volumes. However, the objective necessity of development of small entrepreneurship is caused by changes in large-scale production. As practice shows, small business is a special type of entrepreneurial activity, the essence of which lies in the social division of

Table 2

Dynamics of the quantity of agrarian business entities in Ukraine

\begin{tabular}{|l|c|c|c|c|c|c|c|}
\hline \multirow{2}{*}{ The organizational-economic form } & \multicolumn{9}{|c|}{ Year } & \multicolumn{5}{c|}{$2017, \%$ to } \\
\cline { 2 - 8 } & 2003 & 2005 & 2012 & 2017 & 2002 & 2005 & 2012 \\
\hline Agricultural enterprises - total & 12820 & 8520 & 9180 & 8502 & 66,3 & 99,8 & 92,6 \\
\hline Of them: & \multicolumn{7}{|l|}{} \\
\hline business companies & 6970 & 4733 & 4956 & 4860 & 69,7 & 102,7 & 98,1 \\
\hline private enterprise & 2577 & 1814 & 2268 & 2111 & 81,9 & 116,4 & 93,1 \\
\hline production cooperatives & 2165 & 1041 & 551 & 337 & 15,6 & 32,4 & 61,2 \\
\hline state-owned enterprises & 358 & 271 & 279 & 181 & 50,6 & 66,8 & 64,9 \\
\hline farms & 390 & 437 & 821 & 836 & 214,4 & 191,3 & 101,8 \\
\hline other & 360 & 224 & 305 & 177 & 49,2 & 79,0 & 58,0 \\
\hline
\end{tabular}

Source: calculated according to the State Statistics Service of Ukraine 
Table 3

The efficiency of the development of agrarian entrepreneurial structures in Ukraine

\begin{tabular}{|c|c|c|c|c|c|c|c|c|c|c|c|c|}
\hline \multirow[b]{2}{*}{ Figure } & \multicolumn{4}{|c|}{2005} & \multicolumn{4}{|c|}{2012} & \multicolumn{4}{|c|}{2017} \\
\hline & 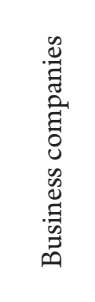 & 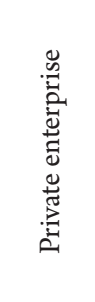 & 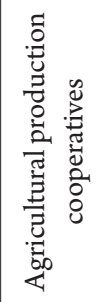 & 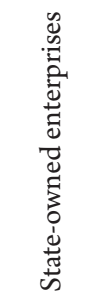 & 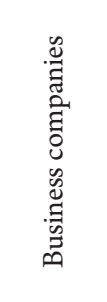 & 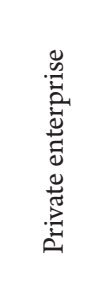 & 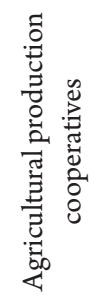 & 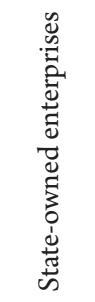 & 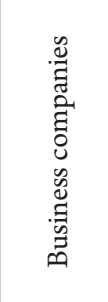 & 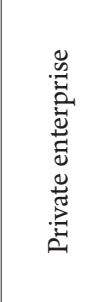 & 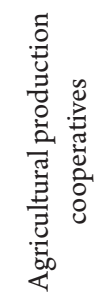 & 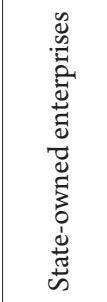 \\
\hline 1 & 2 & 3 & 4 & 5 & 6 & 7 & 8 & 9 & 10 & 11 & 12 & 13 \\
\hline $\begin{array}{l}\text { The number of enterprises, } \\
\text { units }\end{array}$ & 4733 & 2251 & 1041 & 271 & 4956 & 3089 & 552 & 279 & 4859 & 2948 & 340 & 181 \\
\hline $\begin{array}{l}\text { The average area of } \\
\text { agricultural land, ha }\end{array}$ & 1995 & 1702 & 1740 & 2707 & 2241 & 1594 & 1719 & 2099 & 2207 & 1626 & 1604 & 2884 \\
\hline $\begin{array}{l}\text { The average number of } \\
\text { employees ( } 1 \text { entity), persons }\end{array}$ & 97 & 74 & 103 & 157 & 65 & 34 & 68 & 85 & 55 & 30 & 56 & 72 \\
\hline \multicolumn{13}{|l|}{ Gross profit, UAH, per: } \\
\hline 1 employee & 3747 & 2487 & 210 & -466 & 26096 & 34946 & 6951 & 465 & 238217 & 245588 & 89157 & 26879 \\
\hline 1 ha of agricultural land & 182 & 109 & 12 & -27 & 762 & 736 & 274 & 19 & 5968 & 4594 & 3119 & 674 \\
\hline \multicolumn{13}{|l|}{ The level of profitability, \%: } \\
\hline all activities & 10,4 & 9,7 & 1,2 & $-2,1$ & 19,7 & 27,5 & 11,6 & 0,8 & 44,9 & 49,7 & 42,7 & 14,9 \\
\hline crop & 6,9 & 12,5 & 6,5 & 6,0 & 24,5 & 34,2 & 27,5 & 14,1 & 49,8 & 54,5 & 55,7 & 21,7 \\
\hline livestock & 8,5 & 2,7 & $-5,9$ & $-14,7$ & 9,9 & $-0,2$ & $-11,6$ & $-17,1$ & 25,0 & 13,3 & 11,7 & $-12,1$ \\
\hline \multicolumn{13}{|l|}{ Revenue (income), UAH: } \\
\hline per 1 ha of agricultural land & 1935 & 1232 & 1024 & 1289 & 4628 & 3416 & 2638 & 2320 & 19267 & 13842 & 10415 & 5205 \\
\hline 1 employee & 39902 & 28165 & 17307 & 22233 & 158495 & 162129 & 66888 & 57053 & 769003 & 740038 & 297724 & 207489 \\
\hline $\begin{array}{l}\text { Wages of } 1 \text { employee, } \\
\text { UAH/months }\end{array}$ & 366 & 331 & 277 & 424 & 1134 & 1014 & 915 & 1129 & 2502 & 2165 & 1945 & 2099 \\
\hline $\begin{array}{l}\text { The rent for } 1 \text { hectare } \\
\text { of land, UAH }\end{array}$ & 114 & 105 & 103 & 100 & 311 & 283 & 261 & 316 & 1125 & 987 & 936 & 437 \\
\hline \multicolumn{13}{|l|}{$\begin{array}{l}\text { Crop yields, centner from } \\
1 \text { hectare: }\end{array}$} \\
\hline wheat & 30,9 & 30,1 & 27,4 & 30,9 & 29,1 & 26,4 & 26,4 & 26,5 & 43,5 & 38,7 & 38,4 & 31,9 \\
\hline barley & 22,4 & 22,6 & 21,5 & 21,5 & 21,6 & 20,3 & 20,7 & 19,2 & 34,7 & 32,5 & 30,0 & 25,6 \\
\hline corn for grain & 53,6 & 44,2 & 37,4 & 32,9 & 49,6 & 44,9 & 46,5 & 34,4 & 61,8 & 55,7 & 51,8 & 44,1 \\
\hline sunflower seeds & 14,5 & 14,5 & 12,2 & 10,8 & 16,8 & 16,0 & 16,2 & 13,5 & 25,0 & 23,7 & 21,1 & 14,2 \\
\hline sugar beet (factory) & 268 & 261 & 233 & 211 & 292 & 283 & 259 & 219 & 454 & 481 & 382 & 287 \\
\hline \multicolumn{13}{|l|}{ Livestock productivity } \\
\hline $\begin{array}{l}\text { The average annual milk } \\
\text { yield per } 1 \text { cow, kg }\end{array}$ & 2952 & 2975 & 2696 & 3332 & 4201 & 3758 & 3400 & 4147 & 5762 & 5382 & 3624 & 4593 \\
\hline
\end{tabular}

Source: calculated according to the State Statistics Service of Ukraine

labour and allocation of consumers. Its main economic features are: separateness, specialization in any kind of activity, the realization of manufactured goods in the market, can be based on personal labour of the owner and his family members, also uses hired labour. Thus, small business is an independent innovative activity of citizens-entrepreneurs at their own risk with the purpose of gaining business income (Table 4).

The development of the agricultural enterprises must be viewed through the prism of land and property relations; there are many problems in the aspect of the status of the plan relative to land - the main means of production. The land is not institutionally recognized at the state level, commodity economic relations with the involvement of land in economic circulation are in the format of the rent, so this greatly affects the stability of the business model for the structure of subjects of agrarian business, their size, number, the institutional consolidation of farms.

The design of the land of modern domestic agricultural enterprises is such that more than $50 \%$ of the agricultural land involved in the production process, assigned to them through the lease - land is actually raised temporarily (for the term of the lease) capital (Table 5).

Hence, institutional reformatting of the legal subjectivity of enterprises (see Table 2) and we can point to certain manifestations of "temporariness" of the business for private entrepreneurs; therefore, 
Table 4

Key performance indicators of small enterprise structures of the agrarian sector of the economy

\begin{tabular}{|l|c|c|c|c|c|c|c|}
\hline \multirow{2}{*}{ Figure } & \multicolumn{4}{|c|}{ Year } & \multicolumn{2}{c|}{ Deviation of 2017 to 2012 } \\
\cline { 2 - 7 } & 2012 & 2013 & 2014 & 2015 & 2016 & 2017 & $+/-$ \\
\hline $\begin{array}{l}\text { The number of small agricultural } \\
\text { enterprises, units }\end{array}$ & 47213 & 38387 & 44487 & 46906 & 43389 & 44182 & -3031 \\
\hline $\begin{array}{l}\text { The number of employed workers, } \\
\text { thousand persons }\end{array}$ & 219,9 & 197,6 & 220,4 & 238,7 & 218,2 & 203,3 & $-16,6$ \\
\hline $\begin{array}{l}\text { The share of sales by small } \\
\text { enterprises in the total number, \% }\end{array}$ & 22,7 & 27,8 & 30,2 & 30,3 & 30,5 & 32,5 & 9,8 p.p. \\
\hline $\begin{array}{l}\text { The level of profitability of all } \\
\text { activities, \% }\end{array}$ & 11,2 & 21,8 & 16,7 & 8,1 & 9,8 & 32,4 & 21,2 \\
\hline
\end{tabular}

Source: calculated according to the State Statistics Service of Ukraine

Table 5

Characteristics of lease and land relations of agricultural enterprises of Ukraine

\begin{tabular}{|c|c|c|c|c|c|c|c|}
\hline \multirow{2}{*}{$\begin{array}{l}\text { The organizational-economic } \\
\text { form }\end{array}$} & \multicolumn{4}{|c|}{ Year } & \multicolumn{3}{|c|}{$2017, \%$, to } \\
\hline & 2003 & 2005 & 2012 & 2017 & 2003 & 2005 & 2012 \\
\hline \multicolumn{8}{|c|}{ Farmland - all, thousand hectares } \\
\hline Agricultural enterprises - total & 22943 & 16254 & 18454 & 17729 & 77,3 & 109,1 & 96,1 \\
\hline \multicolumn{8}{|l|}{ Of them: } \\
\hline business companies & 13057 & 9442 & 11108 & 11491 & 88,0 & 121,7 & 103,5 \\
\hline private enterprise & 4054 & 3065 & 3328 & 3115 & 76,8 & 101,6 & 93,6 \\
\hline production cooperatives & 3787 & 1811 & 941 & 544 & 14,4 & 30,0 & 57,8 \\
\hline state-owned enterprises & 934 & 734 & 586 & 522 & 55,9 & 71,2 & 89,1 \\
\hline farms & 526 & 765 & 1595 & 1677 & 319,0 & 219,2 & 105,2 \\
\hline other & 585 & 437 & 896 & 379 & 64,8 & 86,8 & 42,3 \\
\hline \multicolumn{5}{|l|}{ Rent, \% } & \multicolumn{3}{|c|}{2017 to:,$+-\%$} \\
\hline Agricultural enterprises - total & 85,9 & 91,5 & 94,8 & 95,8 & 9,9 & 4,3 & 1,0 \\
\hline \multicolumn{8}{|l|}{ Of them: } \\
\hline business companies & 87,7 & 94,9 & 98,2 & 98,7 & 10,9 & 3,8 & 0,5 \\
\hline private enterprise & 94,7 & 98,4 & 97,9 & 98,9 & 4,2 & 0,5 & 1,0 \\
\hline production cooperatives & 89,3 & 95,3 & 97,3 & 98,2 & 8,9 & 2,9 & 0,9 \\
\hline state-owned enterprises & 3,5 & 4,8 & 3,5 & 3,2 & $-0,3$ & $-1,5$ & $-0,3$ \\
\hline farms & 97,0 & 97,5 & 98,4 & 98,3 & 1,3 & 0,8 & $-0,1$ \\
\hline other & 82,6 & 90,5 & 92,4 & 96,0 & 13,4 & 5,5 & 3,6 \\
\hline
\end{tabular}

Source: calculated according to the State Statistics Service of Ukraine

we are not talking about promising efficiency, which would provide not only a market but also social and environmental orientation of the business.

Market institutions' refuse in the sense of tradability of land in a particular way normalizes the alienation of the peasant-proprietor who cannot effectively influence its use. Tenants also are trying to maximize the potential of leased land, constantly being in the institutional trap of possible changes to legislation, other rules of redistribution in the land like a sublease, and so on. The instability of the institutional framework, the uncertainty of the period of the existence of the socalled "hybrid" market of the earth normalizes the temporary nature of the enterprise functioning.

\section{Findings}

In our previous studies, it is noted that "...the best conditions for the production of products with the introduction of innovative technologies are major agroindustrial integrated structures of holding type. They have their own financial institutions or closely related to capital and access to long-term financial debt and the capacity to hold a significant share of the food market. Thus, they limit market access to small and medium enterprises and private peasant farms" (Mesel-Veseljak, 2010). Now the situation is a little different, again, the championship belongs to the big companies, but the number has decreased, although starting to invest in the processing of products, refocus on the domestic market and export products in processed form - as an example, sunflower.

There remains the conclusion that: "the agrarian reform carried out revealed specific features of the transformation period. Introduced artificial conditions without the presence of proper institutional support do not give sufficient economic results. Causes of negative consequences of reforms are the lack of prepared events; 
underestimation of the impact of informal institutions such as habits, traditions; considerable inertia in the development of society; the insufficient level of knowledge and legal education" (Mazur, 2012).

Entrepreneurship - Institute of innovative development of the agrarian sector of the economy, which acts as a means of structural adjustment, the impetus of transformational change through the institutionalization of economic relations in market conditions. However, the Institute of agrarian entrepreneurship has not yet become economically responsible, and excess economic power gives the possibility to dictate conditions for the formation of relations, which are mainly associated with the redistribution of rent in favour of the farmerowner. In particular, institutional owners - peasantslandlords - are in the orbit of an imperfect institutional environment that breeds alienation and motivational conditions for agricultural development.

\section{Conclusions}

Given systematic and analytical characteristics of the effects, significance, dynamics of development of agrarian entrepreneurship in the context of institutional transformation, show the paradox, the stability of the institutional environment will not soon be reached, therefore, the dilemma of institutions remains unresolved. In general, the institutional transformation has ensured the formation of a mixed economy, the real pluralism of forms of ownership and agricultural management even if they are not yet fully institutionalized in the market. Transformations in the business environment we call the transformation of institutional conditions for the development of economic formations. Institute of entrepreneurship for the imperfections of the rules and conditions of economic interactions has not yet become mutually beneficial by the Institute for functional participants.

Analysis of the development of agrarian enterprises in the conditions of institutional transformations proves the inconsistency of the institutional framework of entrepreneurial activity, which leads to a decrease in the number of enterprises - economic entities, nontransparent activities of business entities, the removal of landlords from the participation in the activities of enterprises.

The impact of the institutional mechanisms of business regulation includes a system of base and derived institutions, traditions, organizations, and institutions whose job is to determine the behaviour of economic entities.

In terms of institutional transformation, the development of agricultural entrepreneurship requires the creation of conditions for increasing entrepreneurial activity of economic entities at all levels, the diversification of agricultural and non-agricultural entrepreneurial activities.

The main indicators of development of agricultural business in the village should become: increase of $30 \%$ in the number of businesses.

\section{References:}

Andrijchuk, V. G. (2013). Agropromyslovi formuvannja novogo typu v konteksti strategii rozvytku vitchyznjanogo silskogo gospodarstva [Agroindustrial formations of a new type in the context of the development strategy of domestic agriculture]. Ekonomika APK, 1, 3-15. (in Ukrainian)

Balakirjeva, O. M. (2015). Rozvytok pidpryjemnyctva v Ukraini: instytucijne seredovyshhe ta gromadska dumka naselennja [The development of entrepreneurship in Ukraine: institutional environment and public opinion of the population]. Ekonomika i prognozuvannja, 2, 7-24. (in Ukrainian)

Bergman, X. (1969). Razdelenie truda i specializacija v selskom hozjajstve [The division of labour and specialization in agriculture]. (Ju. I. Timofeeva, O. G. Tropova, Trans). Moskva: "Progresc". (in Russian)

Campbell, J. L. (2004). Institutional Change and Globalization. Princeton and Oxford : Princeton University Press, vol. 4, pp. 121-126.

Commons, J. (1931). Institutional Economics. American Economic Review, 21, 648-657.

Dementjev, V. V. (2009). Shho my doslidzhujemo, koly doslidzhujemo instytuty? [What we study when we investigate institutions?]. Ekonomichna teorija, 3, 75-92. (in Ukrainian)

Freeman, C. (1987). Technology policy and economic performance. London: Printer publishers.

Gadzalo, Ja. M., Lupenko, Ju. O., \& Pugachov, M. I. (2016). Rozvytok ekonomiky silskogo gospodarstva Ukrainy v 2011-2015 rr.: nauk. dop. [The development of the rural economy in $2011-2015:$ the scientific report]. Kyiv: NNC "IAE". (in Ukrainian)

Grebenjuk, V. V. Pro neobhidnist rozvytku malogo pidpryjemnyctva jak osoblyvogo sektoru ekonomiky Ukrainy [About necessity of development of small entrepreneurship as a special sector of economy of Ukraine]. Retrieved from: https://nuwm.rv.ua/metods/asp/v39ek.html (in Ukrainian)

Gubeni, Ju. E. (2012). Pidpryjemnyctvo [Entrepreneurship]. Lviv: NVF “Ukrainski tehnologii'”. (in Ukrainian)

Ivashhuk, Ju. (2016). Emerdzhentnyj instytucijnyj porjadok $\mathrm{v}$ ekonomici ta jogo povedinkovi pidstavy [Emergenti institutional order of the economy and a behavioral Foundation of the]. Ekonomichna teorija, 3, 69-80. (in Ukrainian)

Jeggertsson, T. (2011). Znanija i teorija institucionalnyh izmenenij [Knowledge and the theory of institutional change]. Voprosy jekonomiki, 7, 4-16. (in Ukrainian) 
Jerohin, S. A. (2002). Strukturna transformacija nacionalnoi ekonomiky (metodologichnyj aspekt) [Structural transformation of the national economy (methodological aspects)]. Kyiv: Svit znan. (in Ukrainian)

Khandker, S. R., \& Koolwal, G. B. (2016). How has microcredit supported agriculture? Evidence using panel data from Bangladesh. Agricultural Economics (United Kingdom), 47(2), 157-168.

Kredisov, V. A. (2003). Pidpryjemnyctvo - vyrishalnyj faktor rozvytku krain $z$ perehidnoju ekonomikoju [Entrepreneurship is a decisive factor in the development of transition economies]. Kyiv: Znannja Ukrainy. (in Ukrainian)

Lopatynskyj, Ju. M. (2006). Transformacija agrarnogo sektora: instytucionalni zasady [The transformation of the agricultural sector: institutional framework]. Chernivtsi: Ruta. (in Ukrainian)

Lupenko, Ju. O. (2012). Formuvannja perspektyvnoi modeli silskogo gospodarstva Ukrainy [The formation of a prospective model of agriculture in Ukraine]. Ekonomika APK, 11, 10-14. (in Ukrainian)

Lupenko, Ju. O. (2016). Rozvytok pidpryjemnyctva i kooperacii: instytucionalnyj aspekt [The transformation of the agricultural sector: institutional framework]. Kyiv: NNC "IAE". (in Ukrainian)

Malik, M. J. (2011). Instytuty ta instytucii u rozvytku agrarnoi sfery ekonomiky [Institutions and institutions in the development of the agrarian sector of economy]. Ekonomika APK, 7, 169-177. (in Ukrainian)

Malik, M. J. (2013). Instytuty ta instytucii u rozvytku integracijnyh procesiv v agrarnij sferi [Institutions and institutions in the development of integration processes in agrarian sphere]. Ekonomika APK, 4, 86-93. (in Ukrainian)

Mazur, A. G. (2012). Naukovo-teoretychni zasady systemnyh transformacij v nacionalnij ekonomici [Scientifictheoretical bases of systemic transformations in the national economy]. Ekonomika APK, 5, 158-165. (in Ukrainian) Mesel-Veseljak, V. Ja. (2010). Agrarna reforma i organizacijno-ekonomichni transformacii v silskomu gospodarstvi [Agrarian reform and the organizational and economic transformation in agriculture]. Ekonomika APK, 4, 3-18. (in Ukrainian)

Palmer, T. D. (2014). Moralnist kapitalizmu. Te, pro shho vy ne pochujete vid vykladachiv [The morality of capitalism. What you will not hear from the teachers]. Kyiv: Osnovy. (in Ukrainian)

Pashaver, B. J. (2013). Koncentracija ta efektyvnist silskogo gospodarstva [Concentration and the efficiency of agriculture]. Ekonomika APK, 1, 16-23. (in Ukrainian)

Polterovich, V. M. (2001). Transplantacija jekonomicheskih institutov [Transplantation of economic institutions]. Jekonomicheskaja nauka sovremennoj Rossii, 3, 24-50. (in Russian)

Prutska, O. O. (2003). Instytucionalizm i problemy ekonomichnoi povedinky v perehidnij ekonomici [Institutionalism and problems of economic behavior in transition economies]. Kyiv: Logos. (in Ukrainian)

Rodzhers Everett, M. (2009). Dyfuzija innovacij [The diffusion of innovations]. (V. Starka, Trans). Kyiv: Vyd. dim "Kyjevo-Mogyljanska akademija". (in Ukrainian)

Sabluk, P. T. (1997). Osoblyvosti agrarnoi reformy v Ukraini [The features of agrarian reform in Ukraine]. Kyiv: ZAT "Nichlava”. (in Ukrainian)

Shpykuljak, O. G. (2009). Instytucii agrarnogo rynku [Institutions of the agricultural market]. Kyiv: NNC "IAE" UAAN. (in Ukrainian)

Shpykuljak, O. G. (2016). Instytucijna bezpeka ekonomichnyh agentiv i rynkovyj mehanizm [Institutional security of economic agents and market mechanism]. Ekonomika. Finansy. Menedzhment: aktualni pytannja nauky i praktyky, 5, 80-93. (in Ukrainian)

Schumpeter, J. (2011). Teorija ekonomichnogo rozvytku: doslidzhennja prybutkiv, kapitalu, kredytu, vidsotka ta ekonomichnogo cyklu [The theory of economic development: a Study of profits, capital, credit, interest and economic cycle]. (V. Starka, Trans). Kyiv: Vydavnychyj dim "Kyjevo-Mogyljanska akademija”. (in Ukrainian)

Varnalij, Z. S. (2006). Osnovy pidpryjemnyctva : navch. posib. [Fundamentals of entrepreneurship : tutorial]. Kyiv: Znannja-Pres. (in Ukrainian)

Weber, M. (2016). Hozjajstvo i obshhestvo: ocherki ponimajushhej sociologii [Economy and society: essays on the understanding of sociology]. Jekonomicheskaja sociologija, 5(17), 13-28. (in Russian)

Zbarskyj, V. K. (2015). Ekonomika pidpryjemstva [Enterprise economy]. Kyiv: KyMU. (in Ukrainian) 